\title{
TOWARD AN ETHNOGRAPHY OF THE NATIONAL ECONOMY
}

\author{
HANNAH APPEL \\ University of California, Los Angeles \\ (D) http:/ / orcid.org/0000-0001-7896-3227
}

Each year, the International Monetary Fund (IMF) releases a list of the “World's Best Economies.” Winners in 2013 included South Sudan — the world's fastest-growing economy, and Equatorial Guinea - the economy with the most investment. ${ }^{1}$ If Equatorial Guinea and South Sudan are among our world's "best" economies, it begs the question, what is a national economy? What does it measure, value, or represent? What does it do?

In Equatorial Guinea, as elsewhere, the economy is a privileged objectperhaps the privileged object - in official discourse. State actors and multilateral institutions articulate futures in its terms - development, diversification, growth. In 1983, United Nations rapporteur Fernando Volio Jimenez reported from Equatorial Guinea that "one official after another all the way up to [the president] himself" justified limitations on the press (there was none) and on political participation (political parties were banned) "as being necessary for the focusing of attention on economic issues" (Fegley 1991, 220). More than twenty years later, during my own fieldwork, state officials continued to justify the persistent unreliability of electricity or potable water, not to mention the unremitting limits on the press and on political organizing, citing the need to focus first on economic development. Here, the economy is both an object of the future and a justification for the constant deferral of the present. But what, precisely, is the economy as invoked by the IMF, or by state officials in Equatorial Guinea? Both gesture toward 
a given national economy or, as Timothy Mitchell $(1998,84)$ has defined it, "the structure or totality of relations of production, distribution, and consumption of goods and services within a given country." In this article I attempt to lay some groundwork for an ethnographic approach to national economies as a serial global form, and, by extension, to the geopolitical scale and implicitly bordered categories invoked any time the economy is mentioned.

The national economy form has eluded concerted ethnographic attention, despite its centrality to modern geopolitical imaginaries and its tendency to lurk in the explanatory background of much anthropological work (Wolf 1982). In this article, I ask how national economies become both intelligible, possessing representational unity or naturalized authority, and compelling - the stuff of fantasy and desire, power and subjugation. ${ }^{2}$ My explorations function in dialogue with work in the anthropology of capitalism and the social studies of finance, where questions of markets, market actors and institutions, money, and the expertise of economics have frequently taken center stage. ${ }^{3}$ Often, however, the economy as a thing in itself can remain an underspecified conceptual box, or else a kind of causal context. The economy is not, however, an empty or borderless repository merely populated by markets, financial institutions and actors, labor, commodities, and money. Rather, it is a specific and surprisingly recent sociohistorical and geopolitical formation (Mitchell 2002). Turning our ethnographic attention to it will, I argue, make a contribution not only to the anthropology of capitalism, but also, significantly, to the anthropology of the state. Thus, in this article, I join a handful of authors (Mitchell 1998, 2011, 2014; Holmes 2014; Elyachar 2012; Roitman 2005; Gibson-Graham 1996; Ralph 2015) who, in different ways, have paid explicit attention to the national economy form.

The case of newly oil-rich Equatorial Guinea offers a unique historical moment in which the making and maintenance of something called a national economy was widely (and with some degree of amnesia) considered a new process. Taking a series of national economic conferences in Equatorial Guinea as a point of departure, I trace how and to what effects Equatorial Guinea's national economy was imagined and reproduced through economic theory and desire, futurity and dystopia, state and corporate power. In particular, the ethnographic material shows how an economic theory known as the resource curse shaped and formatted Equatorial Guinea's national economy in the wake of oil. Juxtaposing the scholarship on economic performativity with Equatoguinean political history and the power of U.S. oil companies in the global South highlights the open-endedness and unpredictability of what Michel Callon has called economics "in the wild" (see 
Callon and Rabeharisoa 2003). ${ }^{4}$ Resource-curse theory in Equatorial Guinea not only helped create the world it posited, but also helped create a politically consequential distance between something called the national economy, on the one hand, and local experiences of state violence and corporate power, on the other. Thus, rather than an encompassing process of creating what it purported merely to describe, economic theory in the field created fractured epistemological and political spaces - productive spaces where the world and its representations (here, the national economy) were pulled apart, sitting mismatched alongside one another for all to see. I refer to these as spaces of as-if: misrepresentation, simplification, forgetting, longing. It is, in part, through these productive as-ifs that epistemological objects like national economies come to exercise much of their power, while remaining contingent and contestable.

I begin with a two-part conceptual framing, in an effort to think through how national economies became not only intelligible and compelling but also have tended to slip from anthropology's view. First, extending Timothy Mitchell's (1998, 2002, 2011, 2014) work, I chronicle the mid-twentieth-century moment when the economy, bounded by national borders, began to replace the spatiality of empire. In dialogue with the ethnography to follow, in which the politics of numbers and measurement emerge as central to the story, I note how new techniques of measurement available in this mid-twentieth-century moment (gross domestic product or GDP, for instance) rendered the radically unequal postcolonial order licit and apparently subject to scientific management. This historical interlude ends at the moment when anthropologists "abandoned the study of modern economies to the economists" (Hann and Hart 2011, 14), and I use that moment as the hinge to a brief theoretical section showing how the social studies of finance offers a set of analytical tools designed to interrogate the so-called modern economies that many anthropologists had abjured.

In the ethnographic sections that follow, I trace how the performativity of economic theory - the theory of the resource curse, in particular - unfolded erratically on deeply politicized terrain, producing the fractured spaces of as-if that are as much about state and corporate power as they are about the smooth functioning of economic expertise. I also chronicle the seductive power of something called the private sector, often metonymically taken for the economy, and especially seductive in a place like Equatorial Guinea where the repressive state feels omnipresent. In the conclusion, I open out the theoretical and methodological implications of ethnographic attention to the national economy form: lest we be tempted to imagine Equatorial Guinea as exceptional (which, of course, it is 
in some ways) or generalize only to other African economies or economies of the global South, we need only think about Brexit in relation to the European Union or the collision course between the Anthropocene and economic growth (most often calculated nationally) to begin to imagine the ethnographic possibilities of national economies more generally, as perhaps the most privileged epistemological and political object of our unevenly shared modernity.

\section{THE NATIONAL ECONOMY, IN HISTORY AND IN THEORY}

It was John Maynard Keynes's (1936) The General Theory of Employment, Interest and Money that first posited the economy as a bounded whole, defined by the borders of the nation-state and by the tools states had at their disposal (statistical aggregation, public spending) to manage this ostensibly distinct sphere (Coyle 2014; Mitchell 1998, 2011; Stiglitz, Sen, and Fitoussi 2010). Keynes's (1940) subsequent book, How to Pay for the War, inspired the British state to commission economists to develop the first approximation of what we now call GDP (Coyle 2014). Unlike earlier practices of national income accounting, GDP indicators - the kind the IMF uses for its "World's Best Economies" list — include government purchases and spending in their tally, hence putting national governments at the very center of national economies in at least two ways. National governments are both counted and counter in GDP statistics: "By contrast to purely theoretical liberalism, 'real' liberalism implied for the state a role as organ of economic intelligence, gathering and disseminating information needed by economic agents in order to act in the market" (Desrosières 2003, 557). Thanks to unevenly globalized histories of liberal and neoliberal economic thought, the private sector is often metonymically taken for the economy, despite the fact that, the world over, state budgets and public-sector expenditures account for a large percentage of total GDP (Collier 2005; Mbembe and Roitman 1995; Elyachar 2012). The national economy is, therefore, in the first instance an epistemological project of the state, born in a geopolitical moment in which Western powers were looking for tools to manage the Great Depression, pay for war, and respond to imperial decline. It was at this moment that states increasingly took explicit responsibility for economic activities nominally within their borders and sought statistical tools like per capita income, national income accounting, and GDP through which to know and manage their new charge (Stiglitz, Sen, and Fitoussi 2010; Vanoli 2005). As Chris Hann and Keith Hart (2011, 34) put it, "states claimed the right to manage money, markets, and accumulation in the national interest; and this is why today 'the economy' primarily refers to the country we 
live in” (see also Mitchell 2002; Stiglitz, Sen, and Fitoussi 2010; Vanoli 2005). This, then, is the surprisingly recent history of the banal nationalism (Billig 1995) of the the; why the economy, without scalar specification (municipal, regional, global), reflexively refers to national economies (see also Mitchell 2002).

This history of the present troubles widely accepted teleologies of globalization, in which a world of independent nation-states has recently given way to intensified transnational orders. On the contrary, this recent history shows us that the making of the national was always already responsive to shifting global orders - the end of empire, projects of development, new multilateral institutions, and U.S. hegemony. As empires crumbled in the wake of World War II and anticolonial movements coupled with emergent U.S. hegemony reframed the world as a collection of nation-states (institutionalized in the United Nations, the World Bank, and the IMF), practices of measurement, comparison, and evaluation developed apace. Between 1945 and 1955 the number of countries publishing national-income estimates grew from thirty-nine to ninety-three, and in 1953 the United Nations published the first System of National Accounts (SNA) - a method for national accounting for use by all member states (Speich 2011; Coyle 2014). Again, the year is no accident. The United States had dispensed the equivalent of \$120 billion (in 2016 dollars) through the Marshall Plan, and the United Nations was tasked with tracking these resources: "Countries that wanted to receive postwar aid under America's Marshall plan had to produce an estimate of GDP. . . . To be a nation was, in part, to know your GDP" (Economist 2016; emphasis mine). As I will recount below, we can see this interplay between the transnational and the national in Equatorial Guinea: when oil rents from U.S. multinational firms began to circulate in the late 1990 s, the country was newly knitted into the transnational surveillance regimes of international organizations, bureaucrats, governments, and corporations. This surveillance demanded something newly legible as a national economy that had not been demanded in the same way before oil.

As former colonies became sovereign states, development replaced colonialism as the official framework for relationships across the global North and South (Cooper 2015; Escobar 1995). The statistical tools newly available in this moment-including SNA, per capita income, and GDP - were used to compare newly like sovereign states — suddenly Senegal was "just like" France and could be compared as such. Rather than demonstrating the disastrous relational effects of colonialism, these tools were employed to demonstrate global poverty in ostensibly discrete nation-states and to intervene, now in the name of economic growth. Development, in other words, took the newly measurable national econ- 
omy as its object (Escobar 1995; Mitchell 2002; Speich 2011). The SNA became central to Cold War competition and comparison as well, as communist countries developed the Material Product System (MPS) and Net Material Product (NMP) as countermeasures to GDP (Coyle 2014). Far from mere tools, aggregate economic indicators became an authoritative language of ideological struggle, nationalism, and imperialism. National economies here are both newly legible and newly compelling. To former colonial powers and to the United States as an emergent imperial power, they elide racist colonial history, rendering licit the deep inequalities created by that system. In other words, "the national income view of global inequality did not force Western politicians to reconsider the colonial logic of domination fundamentally. Notions of supremacy, which used to be grounded in cultural considerations, found easy expression in the statistically based language of economic strength" (Speich 2011, 21). These new indicators proved symbolically compelling for newly sovereign nations as well; GDP was both a proud mark of sovereignty and a claim on sovereign interdependency (Cattelino 2008). The terms and conditions of international finance-how big of a loan? at what interest rate? over what repayment term?- have, since this moment, been partially contingent on GDP indicators. The SNA or GDP, then, are compelling symbolic frameworks that generate performative facts and affective sequelae-interest rates, desire, sovereignty, comparability, competition, licit supremacy, nationalism. In their transposability, modularity, and affective intensity, they are both analogous to and constitutive of Benedict Anderson's (1993) idea of the modular nation. "In all instances of national income accounting, the nation-state was reified as a category of knowledge and hence enormously stabilized as a historic entity” (Speich 2011, 22; see also Meyer et al. 1997).

This mid-twentieth-century moment, when the economy, bounded by national borders, began to replace the spatiality of empire precipitated the formalistsubstantivist debate in anthropology, which began with The Great Transformation (Polanyi 2001) and peaked in the 1970s. Economists working in still-colonial Africa turned to anthropologists with questions about nonmarket goods and services, household production, and nonmonetary denominations. It was in part this enrollment of anthropologists in early attempts to quantify African economies that spurred disagreement about the universal applicability of the tools of economics. The substantivists - Karl Polanyi, Conrad Arensberg, and Harry Pearson (1957), Paul Bohannan and George Dalton (1962; see also Dalton 1969), and Marshall Sahlins (1972, 1976) among others - refused the universality of economic calculation and insisted that "the Tiv" or "the Maori" would not recognize something 
called an economy apart from sociocultural life. Consequentially, Polanyi and his followers "abandoned the study of modern economies to the economists" (Hann and Hart 2011, 14). And yet, substantivists' refusal of the calculative techniques of economics could not have anticipated the power, ubiquity, material, and symbolic effects in the world of those forms of representation, now stable enough to lie at the center of global political imaginaries. It seems to be through this history, in part, that national economies slipped into the background of some ethnographic work. It is also through this history, however, that we can recover the centrality of national scale-making, the state, and the post/colonial histories of metrics like GDP to the analytic life of the national economy form.

If the formalist-substantivist debate steered anthropology away from socalled modern economies for a time, the past decade or more has seen a major shift in anthropology, feminist approaches to capitalism, and the social studies of finance in particular. Scholars now put economists, corporations, financial institutions, markets, and even central banking under ethnographic scrutiny. Sifting through this bibliography for sustained attention to the national economy form, however, is trickier. Consider Michel Callon's (1998, 2) groundbreaking Laws of the Markets, which opens by stating that "economics, in the broad sense of the term, performs, shapes, and formats the economy, rather than observing how it functions." This initial statement of the economic performativity thesis - as the proposition that economics performs the economy came to be known - has been tremendously generative for the social studies of finance (MacKenzie 2008; Miyazaki 2013; Holmes 2014), and indeed I take it up ethnographically below. But in the context of attention to scale, the state, and geopolitics, I want to note a common slippage between the economy (invoked without scalar specificity) and the market, or market devices. For example, Callon's $(1998,3)$ book aimed to analyze the relationship between economics and the economy, for which, he says, "the most convenient starting point is the general definition of the market." Indeed, the performativity thesis has paid close attention to markets, market actors, market materialities, and the performativity of economics therein. But the relationship of all this to something called the economy, still less a given national economy, remains unclear. More recently, Koray Çalişkan and Callon (2009, 2010) have urged us to provincialize the economy and to shift our focus to processes of economization (see also Bear et al. 2015). On the one hand, of course I agree; the economy is processual — continually made and remade in daily practice. On the other hand, as I have argued above, the the - that most prosaic and routine of definite articles that Çalişkan and Callon urge us to discard-rhetori- 
cally makes the economy into a geopolitical object whose tacit limit is the nation (Mitchell 2002). Thus, to Callon's (1998; see also Çalişkan and Callon 2009) dictum that there is no economy without economics, this article responds yes, and, there is no economy without the state.

Anthropologists writing in dialogue with the social studies of finance offer material that is more substantively tied to a given economy's geopolitical terrain. Douglas Holmes's (2014) Economy of Words - an in vivo account of macroeconomic thinking as monetary policy in the central banks of New Zealand, Europe, and the United States - has perhaps gone the farthest in this direction. Close attention to the publications and declarations of central bankers leads Holmes $(2014,14)$ to argue that the narratives of central banks "are generative of a communicative field within which and by which the economy is made, remade, and unmade." Following Holmes (2014, 23), I, too, aim to understand "the economy as an empirical fact," yet I am struck by how his account of the economy-emerging from ethnographic intimacy with experts, expert practices, and expert documents - profoundly differs from the more public life of Equatorial Guinea's national economy that I present below. Rather than an economy that central bankers are trying to apprehend and manage both in real time and prospectively, I found an economy to which people were told to subordinate their needs; that people were hopeful they might find and participate in; that laundered sordid dealings between transnational oil companies and the Equatoguinean state into platitudes of economic theory. Where, for Holmes's interlocutors, the economy (he does not specify a scale) is a communicative field of experimentation and intervention, the national economy I present below is a communicated field of political contestation and the sequelae of colonialism. Both approaches (and more!) are necessary.

The ethnographic material below is perhaps in closest dialogue with Bill Maurer's $(2005,2007)$ work on offshore finance in the Caribbean and South Africa, James Ferguson's (1994) on the World Bank's radical misdiagnosis of Lesotho's national economy, or the work of Walter Rodney (1982) and Fred Cooper $(2015,36)$, the latter of whom reminds us that "to see an Africa, Asia or Europe whose economic 'performance' can be compared with each other obscures both the historical mechanisms through which such entities were imagined and constituted and the nature of international connections today." These false equivalences and disavowals of historical connection are precisely the effects of macroeconomic tools like GDP and national growth rate when laid across postcolonial inequality. On the one hand, these tools offer an expert language of comparability and potential equality. On the other, they legitimize and dehisto- 
ricize radical inequality, rendering hierarchies of global supremacy licit in scientific language (Speich 2011). As Equatorial Guinea's national economy is remade with the arrival of major U.S. oil and gas firms, these histories of domination are the terrain on which the fallacies of liberal equality are built.

The ethnography to which I now turn draws attention to the relationship between economic theory - in this case, the resource curse-and something called the national economy on postcolonial terrain. While the performativity of economic theory was robustly present in Equatorial Guinea, the field was also full of performative failures and the multivalent productivity of misfires to economic world-making (Butler 2010). Productive failures bore the national economy in its poetic mode, wherein "the budget must act as if it were a realist representation" (Larkin 2013, 335; see also Mbembe 2001; Mbembe and Roitman 1995). I draw attention to these spaces of simultaneity, between solidity and incompleteness, between performative representations and the world they both (fail to) describe and (fail to) create. These are the spaces of as-if: misrepresentation, simplification, forgetting. Capacious and contentious political spaces, asifs both disturb the smooth performance of expertise and make room for national economies to exercise much of their power.

\section{A NEW NATIONAL ECONOMY?}

In 1997, Equatorial Guinea held its first National Economic Conference. There had been national-level conferences before, but the 1997 conference was distinguished by the fact that it was conceived, documented, and publicized by its state organizers as Equatorial Guinea's "first" national economic conference (República de Guinea Ecuatorial 1997). A U.S. company had discovered oil three years earlier, and small amounts of money from exploratory contracts had just begun to circulate back into the country. This was a dramatic turn of events for a microstate characterized by unprecedented economic collapse in the 1970s and a crippling debt burden by the early 1990s. In December 2007, two months into my fieldwork and ten years after the first national economic conference, flush with oil wealth, Equatorial Guinea held its second national economic conference. Here again, despite conferences on other themes in the interim decade, the "second" designation was an official part of the conference's title: "National Economic Conference II. National Plan for Economic Development. Agenda for the Diversification of Sources of Growth. Equatorial Guinea toward Horizon 2020.” How to understand the idea, implied in those "first" and "second" descriptors, that the national economy, or at least a conference on it, was something new in the wake of oil? Seemingly 
ahistorical or amnesiac, these firsts come into sharper relief by going back briefly into Equatorial Guinea's colonial and immediate postcolonial history.

While Spain gained imperial rights to what was called Spanish Guinea in 1777, it was not until the 1930s that Spanish missionaries had even seen the interior of continental Río Muni, let alone established administrative rule of any kind (Bidyogo 1977; Fegley 1991; Sundiata 1990). While Bioko Island was an economically and politically strategic holding, with increasing Spanish presence if not rule, Río Muni "was viewed as a magnet for the border population (from Gabon and Cameroon) because it was a place where censuses, native taxation, levies, and native justice [were] unknown. According to one French official, it was possible for Africans to live 'in complete freedom' in Rio Muni” (Sundiata 1990, 34). Though Equatorial Guinea's colonial era cannot be characterized homogeneously, processes of foreign administrative rule that were (unevenly) characteristic of other places, including statistical representation, did not capture Equatorial Guinea in the same way.

This exceptional relationship to statistics continued after independence in 1968. In the ensuing years, amid Spanish-backed coup attempts, escalating political tensions, and what Equatoguineans described to me as postindependence leader Macías Nguema's deteriorating mental health, Equatorial Guinea descended into profound violence. In the decade between 1968 and 1978 roughly one-third of the population was killed or fled into exile. During this time, identification as an intellectual was reason to be put to death, and statistics were illegal. "After 1970 there was not one reliable economic figure, government statistic or census report to be found in the country" (Fegley 1991, 72). The man who eventually took power in a 1979 coup_-Obiang Nguema Mbasogo, still president in 2017served as chief of security in the previous regime and was intimately implicated in its brutalities. Obiang's coup brought foreign observers back into the country for the first time, and a Uruguayan lawyer invited to Equatorial Guinea to witness the regime change wrote an account of the economic situation he found in 1979:

The economy was to all intents and purposes paralyzed. The basic serviceselectric power, transport, the post, banking, communications-were virtually at a standstill. . . Macías, as Head of State, took the national treasure to his palace of Nzeng Ayong . . . he administered the funds of the state from his house. . . . Commerce is practically at a standstill in Malabo. There are only a few small shops . . . still open but their shelves are empty. There is not a single restaurant in the whole town. There has been no electric 


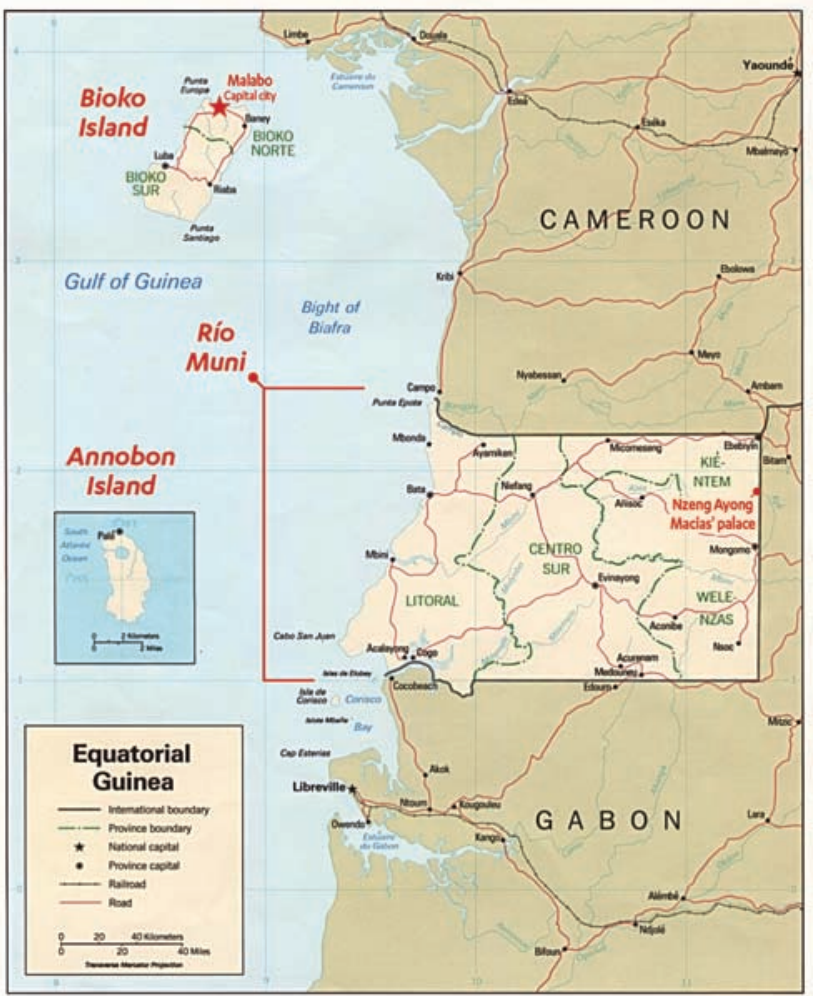

Figure 1. Map of Equatorial Guinea produced by the U.S. Central Intelligence Agency. Annotated by University of California, Los Angeles Document Services.

power since 1978. For four years or so, there has been no written press in the country because, according to the government, there has been no paper. (Artucio 1979, 14-15)

As Randall Fegley $(1991,155)$ summarizes, "nowhere at any time had an economy collapsed in the sense that Equatorial Guinea's had by 1978.”

Though foreign aid poured into Equatorial Guinea with the advent of Obiang's rule and the country joined the Economic Community of Central African States (CEMAC) in 1988, those renewed ties had little effect on an already-fraught relationship to certain forms of knowledge production. During my time in Equatorial Guinea, the Ministry of Finance and Budgets was routinely without electricity for days on end. The street-facing door to the ministry's archives remained constantly ajar, and precariously stacked files and papers escaped into the street, caught by harmattan winds or soaked in the rainy season's mud. When I talked 
to an Equatoguinean lawyer about access to those archives, he quipped, "Here, it is easier to find petroleum than information.” For its part, the International Monetary Fund $(2009$, 16) wrote that "data on the national accounts, balance of payments, and inflation all have significant limitations and make it difficult to get an accurate representation of the performance of the non-oil sector." Note the emphasis on the non-oil sector. Though the report does not specify why, one can infer that oil-industry accounting makes up for the data gap, and that Equatorial Guinea's public administration is contractually obliged to keep certain kinds of records in the oil and gas sector that are not obligatory outside those boundaries.

From erratic colonial administration to the national treasure in Macías's Nzeng Ayong home to the ministry's records soaked in the street, Equatorial Guinea has had a long, fraught relationship with the kinds of enumeration and recording practices constitutive of the national economy form. And yet, as oil money began to circulate in the mid-1990s, that form was interpellated in new ways. An acceptably documented national economy became both newly demanded and newly possible, hailed by the visibility of a single - and singularly profitableglobal commodity. The economy, in other words, does not predate oil in any simple way, as a separate sphere ready to be populated. Rather, the transnational circulation of oil makes Equatorial Guinea's national economy both possible and necessary in new ways. The national, in other words, is always already entangled with the transnational - the lumpy movements of global capital, compliance with international public accounting norms, and what Callon has described as economic theory "in the wild."

Hydrocarbons account for more than 99 percent of Equatorial Guinea's GDP. This reliance on a single commodity — nonrenewable, subject to radical price fluctuations, dominated by foreign expertise and capital, but also wildly profitable for the local state-makes Equatorial Guinea appear to be a case study for the so-called resource curse, a theory out of economics and political science that analyzes the typical oil state and its pathologies. Resource-curse theory suggests that Equatorial Guinea will now become a member of a class of states that includes Nigeria, Venezuela, and Kazakhstan, among others, in which the influx of oil money fuels a distinctive set of economic and political problems including corruption, antidemocratic tendencies, and the maldistribution of oil rents (Ebrahim-Zadeh 2003; Hirschman 1958; Humphreys, Sachs, and Stiglitz 2007; McSherry 2006; Sachs and Warner 1995; for critiques, see Weszkalnys 2011; Mitchell 2011). Both the idea of the resource curse and a subset of this theory, known as the Dutch Disease, circulated widely in Equatorial Guinea. Dutch Disease takes 
its name from the Netherlands, where, after oil and gas discoveries in the North Sea in the 1970 s, revenue from the manufacturing sector plummeted. This socalled disease now refers to resource-rich countries' overreliance on oil, to the detriment of other productive sectors. Economists prescribe diversification away from oil-agriculture! tourism! IT! — as the treatment for this malady.

Note how resource-curse theory moves the national economy in both time and space, framing it as something out there in the future to be diversified, separating it from both local histories and the involvement of transnational corporations, causally tying its fate instead to the translocal properties of hydrocarbons. While I discuss the ethnographic life of economic theory and the resource curse in particular at length below, here I want to flag its power to disentangle the world from its representation (see also Mitchell 2002). Where the performativity program shows the world and its representation to be co-constitutive, there are moments when the distance between them becomes the space of politics and power; the world sitting uneasily alongside its representation: the space of as-if.

\section{UTOPIA AND DYSTOPIA I: The Resource Curse and Salt into Gold}

At the 2007 conference, the president and ministers of government, oil company representatives, national and international business owners hoping to invest, the World Bank, the IMF, USAID, European Union delegates, Washington, D.C. lobbyists, and regional diplomats were all brought together in the name of the future: Horizon 2020. After an initial day of opening ceremonies and closed-door meetings, Day 2 presented conference participants with four concurrent, daylong sessions - infrastructure, social sector, public sector, and private sector. I followed the decidedly largest portion of the crowd into the privatesector session.

On entering the room, assistants handed each attendee a plastic carrying case, modeled after a briefcase, containing more aggregated information about Equatorial Guinea than had arguably ever been released to the public. Given the histories of information narrated above, the conference's printed material was startling. Each plastic briefcase included three booklets of seventy-five pages each. Printed in vibrant color with extensive graphs and charts, the first booklet offered an economic and social diagnosis of the country; the second, strategies for improving that diagnosis over the coming thirteen years; and the third, a poverty profile. The package also included five smaller booklets of demographic and statistical analysis. As we waited for the proceedings to begin, audience members 
marveled audibly at the material. Where did it come from? Who wrote it? Who produced the statistics? Is there any reason to think that any of it is accurate? The (re)production and circulation of oft-repressed forms of information coupled with economic theory-making turned these booklets into what one informant aptly called "dream papers." At the conference and afterward, many shared the sentiment that the materials were more daydreams spun atop economic theory than reliable representations of an external economic reality. This is the space between the world and its representation as ethnographic fact. What is possible in these spaces? What happens here?

The dream papers came to life through long hours in the private-sector session, as the minister of mines, followed by representatives from state oil and gas companies and then a German agro-businessman seemingly in the process of brokering a large deal with the government, narrated one after another a future at once utopic and surreal. I transcribe (in translation) excerpts from each of these narrations, intentionally stringing them together to evoke the surrealism of their progression.

In the energy sector, the government will build two conditioning plants to make gas available for local use and diminish ongoing reliance on foreign processing. It will also construct a modular refinery in the country to bring down prices. By 2020, state-of-theart facilities in Equatorial Guinea will monetize the gas that is currently burned off in the petroleum-production process not only here, but also in Cameroon and Nigeria.

The potential for the fishing industry is colossal, with an estimated local capacity of sixty-five thousand tons per year, the equivalent of one hundred million U.S. dollars. The government will build two industrial centers and ice factories to service this industry. It will educate oceanographers and boat engineers. By 2020 there will be a fleet of industrial fishing ships and an industry producing value-added products for export, including salted, dried, and smoked fish, canned and packaged products, and modern fish farms. Annobón will be the center of the industry, where women will be transformed into commercial fishers.

Equatorial Guinea has the richest soil in the world for tropical cultivants. By 2020 local agriculture will supply one hundred percent of nutrition needs, and there will be more for export. The forests of 2020 will be conserved. Tourism, too, is an important world industry that generates employment and eradicates poverty. Equatorial Guinea will be a destination for luxury and business tourism, offering endemic-species safaris, sumptuous lodges on remote islands, and innumerable opportunities to invest while you recreate.

Small businesses and the entrepreneurial sector are the priority in this process. The private sector must drive the economy. This will require microfinance, small business loans, export infrastructure, transparent access to credit for small businesses. But the pure gold, 
the German man suggested as the session concluded, is in salt. The production of salt here, alongside caustic soda and chlorine, is the first step in modern industrialization, and then into the real chemical industry: plastic and other petroleum products that turn salt into pure gold.

As he hurried to get through his last improbable sentences, having been told repeatedly and loudly to end his presentation, the minister of mines finally stood to conclude the session. By 2020, Equatorial Guinea will be a successful African model of the transition from a petroleum economy to a diversified economy. Equatorial Guinea will be the first country in the global South to have avoided the resource curse.

The salt-into-gold future was narrated by each presenter and detailed in the printed materials as a route through the predictions of economic theory. That both the conference presenters and the printed materials presented the Dutch Disease, in particular, as a looming threat was incongruous in multiple ways. First, the country had been without a productive agricultural sector long before the discovery of oil, let alone other industries for either domestic consumption or export. Far from a disease contracted in relation to oil, the rise and fall of a once-profitable cocoa industry had everything to do with colonial and postcolonial relationships between Spain and Equatorial Guinea, Nigerian and Liberian labor, Fernandino land owners, ${ }^{5}$ contemporary struggles over imports from Cameroon, and internal private-property issues. Moreover, with once oil-rich Gabon just across the country's eastern border and with the offshore platforms of Nigeria visible on clear nights from the shores of Malabo, Equatoguineans did not need an economic theory to understand the complex perils of becoming an oil exporter, which clearly had everything to do with the toxic cocktail of transnational oil companies and local politics. And yet, many at the conference welcomed a narrative that could lay these outcomes at the foot of a resource and not at the feet of either local or transnational power. The resource curse provided a safe, causal, and authoritative narrative that replaced local histories of power and ownership, offering a modular explanation for social and economic ills that moved responsibility in both time and space: away from grounded local histories and toward futures, already seen elsewhere, ostensibly inherent in the qualities of the resource. The conference became about avoiding a potentiality out there as opposed to reorganizing power distributions in here. Economic theory-the resource curse — was opening a politically consequential distance between something called the national economy, on the one hand, and local experiences of state violence and corporate power, on the other. Yet layers of dystopian presents and pasts burdened each of the conference's utopic visions, requiring tremendous public 
acts of forgetting and future-oriented confabulation. On what fictions and forgetting does the making of a thing called a national economy depend ? $^{6}$

The projected fishing industry, for instance, would require a program of environmental controls for off-platform pollution, and yet according to my Equatoguinean interlocutors working on oil rigs, as of 2009 there had not been a single independent environmental review of Equatorial Guinea's offshore industry. For the education of oceanographers and engineers, the country had one functioning university, which during my fieldwork had sporadic electricity, a library of perhaps fifty books, and six computers belonging to an American study-abroad program doing research on primates (known locally as los monkeys). A slightly deeper history of the fishing industry and Annobón's prospective role therein takes us back to 1975, when Macías outlawed doctors (as part of what he perceived to be the foreign-trained and treasonous intellectual class) and half of the island's inhabitants died for lack of medical care. During my fieldwork, one could only get to Annobón by boat - a state-owned ferry service that was notoriously unreliable and often diverted to Bata. A new airport was under construction on Annobón, however, and though quoted airfares would be prohibitively expensive for the majority of those commuting to and from Annobón for their livelihoods, the airport was central to the imagined tourism industry, allowing access to Annobón's exquisitely beautiful, sparsely populated beaches. Annobón's future as a tourist utopia of untouched beaches conveniently depopulated by leprosy and other forms of political violence is overlaid not only with the island's history, but also with contemporary forms of surveillance throughout Equatorial Guinea. During my fieldwork, maps were illegal, as was photography in cities or anywhere in view of a policeman or soldier. While websites and tourist brochures advertise the beautiful views to be had from atop el Pico, the mountain that rises along Malabo's southwestern edge, soldiers guarded the road up the mountain. In my fourteen months in Equatorial Guinea, I was never able to secure permission to go up.

The utopian agricultural future totters uncomfortably on the brink of dystopia as well. Historically, labor in Equatorial Guinea's cocoa industry was provided largely by migrants, first Liberians and then Nigerians (Campos Serrano and Micó Abago 2004). Within five years of independence, Macías began to stop paying the Nigerians, who left en masse. In their place, Macías decreed a compulsory labor act for Equatoguinean citizens in 1972, sparking mass exodus. Since the precipitous decline of cocoa production that followed, Equatorial Guinea has had no industrialized agriculture. While much of the population outside major cities is involved in both subsistence farming and the selling of small surpluses, 
bulk agricultural products are, on the whole, imported from Cameroon. Less than a month after the conference's proclamations on the future of agriculture, the then minister of agriculture and forestry (the president's much-maligned son Teodorín) was shown on television literally throwing money and basic tools to elated farmers, arms outstretched.

To imagine that the resource curse could begin to account for present challenges, or point clearly to ways of strengthening or diversifying something called the national economy in the wake of these histories, would be laughable - deconstructable, in fact - if it did not have so much power. Economic theory here opens a distance between literally unspeakable local histories and something called a national economy.

\section{UTOPIA AND DYSTOPIA II: Private-Sector Desire}

The surreal utopias presented at the conference were not the product of resource-curse theory alone. These detached, idealized private-sector fantasies were also deeply rooted in local experiences of a suffocating authoritarian regime, and in translocal imaginings of the endless riches to be had on the Equatoguinean frontier. Despite, or perhaps because of the mirrored surrealisms of a fishing sector amid unimpeded offshore pollution and a tourism industry without maps or cameras, I repeatedly found myself in the unexpected position of cheering for this imaginary object of desire called a private sector. I was not alone. The as-if distance opened up by economic theory, the putative safety of a separable sphere called the national economy, does not have a single political valence. It does not only work in the service of power. At this conference and beyond, it also enabled critiques of the Equatoguinean regime and its complicity with U.S. oil companies that were otherwise untenable and even illegal.

One of the first audience members to ask a question after the surreal narration of future utopias was Alberto, who happened to live in the apartment above mine and was the head of the Equatoguinean delegation for small businesses. Obliquely referencing the amnesias of the conference, he reminded the audience of a 1982 national forum on the promotion of business, and of the 1997 conference, where the private sector had also been established as the motor of development. After these reminders, he asked, "Where are we now? We need financing and access to credit, education, good labor conditions, access to technology, and a fiscal climate according to the law. I'm no xenophobe," he continued, "but foreign companies are granted all the big contracts, and then we're hired at dismal wages as subcontractors. I have the capacity but I lack the capital. If I had the 
money, I, too, could subcontract an architect or an engineer.” When he finished, the conference room erupted in boisterous applause and full-throated cheers, and he turned and smiled and waved at the crowd. His question was a thinly veiled critique of the state and of iterative conferences that came to the same conclusions yet produced nothing-no credit, no education, no fiscal climate according to law, no disengagement of the state from its control of the private sector. Despite these serial failures, the enthusiastic response to his question revealed that the conference and its imagined private sector offered the opportunity, otherwise unavailable, for people to gather in large numbers and cheer loudly at indirect critiques of the regime.

For many in Equatorial Guinea, this imagined private sector was the preferred realm of fantasies of freedom and opportunity. While these fantasies were certainly not evenly shared, neither were they the exclusive daydream of the wealthy or well-connected. These desires stretched from impoverished young hip-hop artists who had to go to Gabon to find a recording studio free of government or official Spanish sponsorship/censorship to young Americans working in an "MBAs without Borders" program who were shocked at the extent to which, as they put it, "Big Brother is watching everything in Equatorial Guinea." A private sector detached from this pervasive feeling of surveillance and control felt downright radical. Here, I want to explore different moments of this desire for and idealization of a future private sector, thinking through its ambivalent character of subversion, on the one hand, and the intimate subvention of state power, on the other.

On weekends in June and July 2008, Orange - the central brand of France Telecom, at that point trying to make inroads into the cell-phone market in Equatorial Guinea - sponsored a free music and dance festival, setting up a stage and sound system in the public plaza around Malabo's city hall. Replete with obnoxious recorded advertisements about Orange goods and services blaring between youthful acts, the festival allowed for something that rarely happened in Equatorial Guinea: free public art and an open-air public gathering, seemingly unrelated to the regime. I attended the festival nearly every weekend, joining a small crowd that was mostly groups of teenagers with younger siblings in tow, though a little bit of everyone skirted the event's edges, curious about the unusual public spectacle. Whereas alabaciones (political propaganda songs) flooded the official music industry, whose only source of income was the state, the Orange summer stage boasted not a single song praising Obiang or the regime. Indeed, 
several songs critiqued him, directly or indirectly. There was even a song about marijuana.

With labor and event management subcontracted to a small Equatoguinean media company owned by a young Equatoguinean recently returned from life and education abroad, the audience was clearly seduced by what Orange and its local collaborators were able to facilitate. In a place where dissent was reduced to hushed conversations around dinner tables, the spaces that private enterprise seemed to open up — like this Orange stage - felt oddly radical and out of control. Like Alberto, who felt free to critique the state at a conference on the economy, on the Orange stage, too, the private sector in its own image became a felt space of possibility and unpredictability for the Equatoguinean youth performing, for those of us in the audience, as well as for the mayor herself, whom I watched leave in a huff during the marijuana song. Rather than dismiss everything that happened on the Orange stage that summer — or, indeed, fantasies of the private sector in general — as always already compromised by some essential evil of capitalism, I follow Hirokazu Miyazaki (2013) and others in suggesting that to take the economy seriously in part means to take seriously people's fantasies about it.

The seduction of the private sector was a common trope with which to narrate what was and was not possible in Equatorial Guinea. Take Feliciano, another recently returned Equatoguinean man working for a software company with a contract to digitize the social security system. He noted with some pride that, in his estimation, this work challenged ethnic and other local divisions, implying that those divisions were exacerbated by the handwritten, inconsistent record-keeping practices that his company sought to put in the past. He told me that his project would bring real change "if we don't get kicked out first." I smiled and said that I, too, was hoping not to get kicked out, to which he replied, "Oh, but we're not an NGO. We're a business, in it to make money." The difference, he explained, was in the politics: NGOs represent political interests, and are thus more likely to be kicked out. Profit, on the other hand, is apolitical. While Feliciano knew that I was a researcher affiliated with a foreign university, unattached to any NGO, my lack of any profit motive placed me on the political side of a line. It was only profit that offered safe haven in a place where getting kicked out was a real historical and contemporary possibility.

From the Orange summer concert series to Feliciano's conviction that the profit motive sheltered his company's presence and potential to foment social change, the feeling that the private sector was variously unencumbered and full of potential was pervasive. And yet, it is precisely because private profit is almost 
entirely of a piece with public power in Equatorial Guinea that it seems to operate so freely. In other words, while the national economy undeniably opened up contingent and unstable spaces of expression, dissent, or opportunity for private gain, it was fundamentally a state-sanctioned and state-building project. As one private development worker put it, "if you come with the right partners," you can pretty much do what you want, gesturing to the need to collaborate with a local liaison, or socio, in all business ventures. Decree 137, which mandated that all businesses be at least 35 percent locally owned, made the role of socio a common one for Equatoguinean state personnel or high-powered individuals, put on retainer to serve as government liaison. Foreign companies licitly paid a socio to protect their interests, move their ideas and needs ahead, and get their paperwork through. Thus, while Feliciano was excited that his company pushed against localisms of various kinds, the company also used those very localisms (referred to as enchufes or "plugs" into the system) to ensure success. The idealized private sector that beckoned with boundless future utopias of fishing and tourism, and that lured those of us living in Malabo's boom times out into summer evenings for corporate-sponsored concerts, is unmistakably entangled in the knot of Equatorial Guinea's state apparatus and U.S. oil firms, a knot made licit by the seriality of the national-economy form.

\section{CONCLUSION}

On the closing day of the 2007 conference, participants were noticeably tired. People straggled into the conference hall late; there were fewer animated discussions in the hallways. After evenings spent discussing the event over dinners with Equatoguinean friends, our conversations, too, had grown tired, moving from early laughter at the impracticable goals toward the torpor of long days and wasted time. I sat and sat with other audience members that final morning, waiting for the president to appear, slowly sinking down in our chairs, wrinkling our clothing, and trying to hush our growling stomachs. I wrote in my notebook: the future is exhausting. Finally, the voice of the president's announcer roused us from our slumps, and the president's Moroccan security guards strode in before him. The audience clapped in rhythm, and Obiang joined in as he walked to his seat at the head table.

Then, for a moment, it was as if the impossible future gave way and the dystopia of the present slipped in. In front of the president and others seated at that front table, government presenters elaborated with a bluntness that surprised me the serious and obvious problems the country would have to overcome to 
achieve its goals. Again, I transcribe in translation from multiple presenters: We are essentially without all basic social services. There is little to no running water, none of it potable. Electricity is sporadic in the cities, and not distributed throughout the territory. The health sector is essentially nonexistent for the majority of the country's residents, and the education sector is little better. There is no transparent access to credit for businesses, and no regularized process according to which one might start a business. There is a total lack of legal instruments or regulation in any and all sectors. There are serious problems with private property and contract law. In fact, there is no state contract law.

In Equatorial Guinea, we see that the economy with the most investment in the world operates without contract law; that the resource curse-used to serially diagnose the maladies of resource-rich states - often finds little empirical traction; that something newly legible and publicized as a national economy can come into being, as if new, in the wake of a commodity boom; and that this object opens up unpredictable political spaces in which power can both consolidate and be newly vulnerable. All of this tells us that when we assume to know what a national economy is and what it does, we do so at our peril. Ethnography can help us trace the sites, practices, people, documents, daydreams, and institutions that continuously remake the national economy as a serial global form.

The historical particularity of Equatorial Guinea at the turn of the millennium allows the national economy to pop into a certain kind of visibility. There is a temptation, therefore, to think about Equatorial Guinea as exceptional, to think about local histories of information and statistics, for instance, as incomparable. And of course, Equatorial Guinea is exceptional in some ways. If we are willing to think a little more broadly, it is tempting to think of data and statistics in Africa or the wider developing world as exceptionally thin or untrustworthy. But when recent studies in France and the United Kingdom claim that "only onethird of citizens trust official figures" (Stiglitz, Sen, and Fitoussi 2010, 10), we see that we have a broader question on our hands. The affect-laden spaces of asif - misrepresentation, simplification, forgetting, longing, outrage-where world and representation are pulled apart make room to ask about local and transnational histories of power and ownership, as Alberto did. The as-ifs disrupt the representational singularity of a given economy, the farce that we all have a common relationship to it, a shared interest in how it fares (see Rae and Drury 1993). Similarly, while the Equatoguinean government may be exceptionally coterminous with the private sector, we see that across member countries of the Organization for Economic Cooperation and Development total government output accounts for nearly half of GDP (Stiglitz, Sen, and Fitoussi 2010), destabilizing an approach 
to national economies that metonymically privileges markets, or the so-called private sector. When we think about national economies, we are always already thinking about the state, even as our desires, fantasies, and critiques may take us elsewhere, as they did on the Orange summer stage or with Feliciano's software company. Our theoretical approaches should acknowledge not only private-sector desires, but also their empirical inadequacies and political collusions.

In its bluntest representation, an economy at a given scale is a statistical aggregate, one widely acknowledged as distressingly approximate and incomplete at best. But of course, at the same time, the economy is arguably the most powerful singularity of our contemporary world. Anthropology has the capacious and creative empirical task not of putting questions about history, colonialism, fantasy, epistemology, information, and the state back in (as if the economy was, in fact, disembedded from them), but of showing them to be always already constitutive of this thing called the economy, especially at the scale of the nation, though certainly not only there. Once we develop the methodological tools to understand how national economies are fabricated and to what effects, new theoretical terrain opens up. For instance, the idea of a national economy is clearly specious, and yet it is one of the structural effects that maintain the power of the nation-state. Given the ways that national economies were compelling to newly sovereign states in the postcolonial moment, a wealth of historical and archival projects remains to be done. ${ }^{7}$ How might those projects decenter the Western, Keynesian history I narrated above? Or, given the privileged position of national economies in development thinking, what might an ethnographic account of economic growth — most often calculated nationally - look like? More work on national economies could help us think through the intersection of growth imperatives with the imperatives of the Anthropocene.

The particular violence of the national economy form in the global South, and the enrolling of economic theories like the resource curse in that violence, entreats ethnographic attention. Independence-era Senegalese political leaders Mamadou Dia and Leopold Senghor were prescient in their concerns that, even as they fought for political independence from France, relational inequality between colonizers and soon-to-be nation-states would not be undone by "nominal independence" (Cooper 2015, 68; see also Pierre 2012; Ralph 2015) in a world they insisted was increasingly interdependent. The sequelae of their concerns live on, thrumming in those moments when world and representation are not one, when development plans and economic theory occlude transnational corporate power, when performativity is not so complete that the model becomes the 
world. These are the spaces of political possibility within the foreclosures of modern politics. To find them is to participate in the classic ethnographic project of making the familiar strange: "Given the centrality of the economy to modernist social representations . . . it is necessary to defamiliarize the economy as feminists have denaturalized the body, as one step toward generating alternative social conceptions and allowing new political subjectivities to be born" (Gibson-Graham 1996, 97).

\begin{abstract}
What is a national economy? What does it measure, value, or represent? What does it do? This article argues for ethnographic attention to national economies as a serial global form, arguably the most privileged epistemological and political object of our unevenly shared modernity. In dialogue with feminist approaches to the study of capitalism, economic anthropology, and the social studies of finance, this article asks how national economies become both intelligible, possessing representational unity or naturalized authority, and compelling - the stuff of fantasy and desire, power and subjugation. Taking a series of national economic conferences in Equatorial Guinea as a point of departure, the article argues for the centrality of the state and questions of geopolitical scale in any approach to the national economy form. Juxtaposing the literature on economic performativity with Equatoguinean political history and the power of U.S. oil companies in the global South highlights the open-endedness of what Michel Callon has called economics "in the wild" and the as-if qualities generated at the crossroads of economic theory and postcolonial inequality. This article thus aims to open up ethnographic possibilities in the face of national economies far beyond Equatorial Guinea's borders. [national economy; economics; oil; Equatorial Guinea; colonialism]
\end{abstract}

\title{
NOTES
}

Acknowledgments Thanks very much to the editorial team at Cultural Anthropology and to the anonymous reviewers for bearing with this article and transforming it for the better. I also thank Hilary Chart and James Ferguson for early, helpful comments. I benefited greatly from presentations of this material at Brown University, Harvard University, the University of Chicago, the University of California, Irvine, and the University of California, Los Angeles. Over the course of those presentations Gregory Mortenson, Soo-Young Kim, William Mazzarella, Sean Mallin, Taylor Nelms, Lieba Faier, and Adam Moore all gave invaluable feedback that they should recognize in these pages. Taylor Nelms, in particular, held my intellectual hand through many rounds of revision. I extend particular thanks to the organizers of the "Historicizing the Economy" conference at Harvard, Dan Hirschman, Adam Leeds, and Onur Ozgode, and also to Alden Young, whose work has been an inspiration for many years. Research in Equatorial Guinea was funded by the National Science Foundation, the Social Science Research Council, and Fulbright-Hays. Final and enduring thanks to friends and interlocutors in Equatorial Guinea. Por una Guinea verdaderamente mejor. Por una industria mejor.

1. Most investment is calculated on the basis of total government and private-sector investment, as a percentage of the GDP. In Equatorial Guinea, this is oil money pouring 
in. "Fastest growing" is calculated by GDP growth, which was 24.7 percent in South Sudan, the world's newest country. I thank James Ferguson for initially drawing my attention to the IMF list.

2. Thanks to William Mazzarella for the original formulation of national economies as not only intelligible, but also compelling.

3. These include projects on markets (Callon 1998; Çalişkan and Callon 2009, Çalişkan 2010; Elyachar 2005; Riles 2011; Tsing 2015); financial institutions and actors (Ho 2009; Miyazaki 2013); corporations and firms (Yanagisako 2002; Welker 2014; Kirsch 2014; Golub 2014); money, monetary regimes, and central banking (Maurer 2011, 2012; Peebles 2011; Holmes 2014); and the expertise - performative and otherwiseof economics and economists (Callon 2007; Fourcade 2010; MacKenzie 2008).

4. On the unpredictability of economic performativity, see also Butler 2010, Bear et al. 2015, and Narotzky and Besnier 2014.

5. Fernandino (named after Fernando Po, the colonial name for Bioko Island) generally refers to two colonial-era groups in Equatorial Guinea. It includes the children of Spanish fathers and Bubi mothers who, by virtue of their mixed-race parentage, were considered emancipados (emancipated) under colonial hierarchies and were thus entitled to own land and exercise other privileges not accorded other Equatoguineans. The term also refers to the descendants of English-speaking freed slaves who returned from the United States to Sierra Leone and Liberia, and were later forced to migrate to Equatorial Guinea as laborers. Arriving with substantial formal education compared to the local population and also considered emancipados, this group of people intermarried and worked closely with the British, who had a colonial presence on Fernando Po for roughly fifty years starting in 1826. Eventually, these Fernandinos became large landowners, and many of their land claims persist into the present.

6. For answers to this question in other geographies, see Harris 1993, James 1938, Moreton-Robinson 2015, and Williams 1944.

7. See Alden Young's $(2014,2017)$ work on Sudan, where GDP growth metrics were published weekly on the front page of the national newspaper in the wake of independence from Britain and Egypt.

\section{REFERENCES}

Anderson, Benedict

1993 Imagined Communities: Reflections on the Origin and Spread of Nationalism. New York: Verso. Originally published in 1983.

Artucio, Alejandro

1979 The Trial of Macías in Equatorial Guinea: The Story of a Dictatorship. Geneva: International Commission of Jurists.

Bear, Laura, Karen Ho, Anna Tsing, and Sylvia Yanagisako

2015 "Gens: A Feminist Manifesto for the Study of Capitalism." In "Generating Capitalism," edited by Laura Bear, Karen Ho, Anna Tsing, and Sylvia Yanagisako, Theorizing the Contemporary series, Cultural Anthropology website, March 30. https: / / culanth.org/fieldsights/652-gens-a-feminist-manifesto-for-the-studyof-capitalism.

Bidyogo, Donato Ndongo

1977 Historia y tragedia de Guinea Ecuatorial. Madrid: Editorial Cambio.

Billig, Michael

1995 Banal Nationalism. Thousand Oaks, Calif.: SAGE.

Bohannan, Paul, and George Dalton, eds.

1962 Markets in Africa. Evanston, Ill.: Northwestern University Press.

Butler, Judith

2010 "Performative Agency." Journal of Cultural Economy 3, no. 2: 147-61. https:// doi.org/10.1080/17530350.2010.494117. 
Çalişkan, Koray

2010 Market Threads: How Cotton Farmers and Traders Create a Global Commodity. Princeton, N.J.: Princeton University Press.

Çalişkan, Koray, and Michel Callon

2009 "Economization, Part One: Shifting Attention from the Economy toward Processes of Economization.” Economy and Society 38, no. 3: 369-98. https:// doi.org/10.1080/03085140903020580.

2010 "Economization, Part Two: A Research Program for the Study of Markets." Economy and Society 39, no. 1: 1-32. https://doi.org/10.1080/ 03085140903424519.

Callon, Michel

1998 "Introduction: The Embeddedness of Economic Markets in Economics." In Laws of the Markets, edited by Michel Callon, 1-57. Malden, Mass.: Blackwell.

2007 “What Does It Mean to Say that Economics is Performative?" In Do Economists Make Markets? On the Performativity of Economics, edited by Donald Mackenzie, Fabian Muniesa, and Lucia Siu, 311-57. Princeton, N.J.: Princeton University Press.

Callon, Michel, and Vololona Rabeharisoa

2003 "Research 'in the wild' and the Shaping of New Social Identities." Technology in Society 25, no. 2: 193-204. https://doi.org/10.1016/S0160-791X(03)000216.

Campos Serrano, Alicia, and Plécido Micó Abago

2006 "Labor and Trade Union Freedom in Equatorial Guinea." Madrid: Fundación Paz y Solidaridad Serafín Aliaga.

Cattelino, Jessica

2008 High Stakes: Florida Seminole Gaming and Sovereignty. Durham, N.C.: Duke University Press.

Collier, Stephen J.

2005 "Budgets and Biopolitics." In Global Assemblages: Technology, Politics, and Ethics as Anthropological Problems, edited by Aihwa Ong and Stephen J. Collier, 373-90. Malden, Mass.: Blackwell.

Cooper, Frederick

2015 Africa in the World: Capitalism, Empire, Nation-State. Cambridge, Mass.: Harvard University Press.

Coyle, Diane

2014 GDP: A Brief but Affectionate History. Princeton, N.J.: Princeton University Press.

Dalton, George

1969 “Theoretical Issues in Economic Anthropology." Current Anthropology 10, no. 1: 63-102. https://doi.org/10.1086/201011.

Desrosières, Alain

2003 "Managing the Economy." In The Cambridge History of Science, Volume 7: The Modern Social Sciences, edited by Theodore M. Porter and Dorothy Ross, 55364.

Ebrahim-Zadeh, Christine

2003 "Dutch Disease: Too Much Wealth Managed Unwisely." Finance and Development 40, no. 1. http://www.imf.org/external/pubs/ft/fandd/2003/03/ebra.htm.

Economist

2016 "The Trouble With GDP." April 30. http://www.economist.com/news/ briefing / 21697845 -gross-domestic-product-gdp-increasingly-poor-measure-

Elyachar, Julia prosperity-it-not-even.

2005 Markets of Dispossession: NGOs, Economic Development, and the State in Cairo. Durham, N.C.: Duke University Press. 
2012 "Before (and After) Neoliberalism: Tacit Knowledge, Secrets of the Trade, and the Public Sector in Egypt.” Cultural Anthropology 27, no. 1: 76-96. https:// Escobar, Arturo doi.org/10.1111/j.1548-1360.2012.01127.x.

1995 Encountering Development: The Making and Unmaking of the Third World. Princeton, Fegley, Randall N.J.: Princeton University Press.

1991 Equatorial Guinea. Santa Barbara, Calif.: Clio Press.

Ferguson, James

1994 The Anti-Politics Machine: "Development," Depoliticization, and Bureaucratic Power in Lesotho. Minneapolis: University of Minnesota Press.

Fourcade, Marion

2010 Economists and Societies: Discipline and Profession in the United States, Britain, and France, 1890s to 1990s. Princeton, N.J.: Princeton University Press.

Gibson-Graham, J. K.

1996 The End of Capitalism (As We Knew It): A Feminist Critique of Political Economy. Oxford: Blackwell.

Golub, Alex

2014 Leviathans at the Gold Mine: Creating Indigenous and Corporate Actors in Papua New Guinea. Durham, N.C.: Duke University Press.

Hann, Chris, and Keith Hart

2011 Economic Anthropology: History, Ethnography, Critique. Malden, Mass.: Polity Press. Harris, Cheryl I.

1993 "Whiteness as Property." Harvard Law Review 106, no. 8: 1707-91. https:// doi.org/10.2307/1341787.

Hirschman, Albert O.

Ho, Karen

1958 The Strategy of Economic Development. New Haven, Conn.: Yale University Press.

2009 Liquidated: An Ethnography of Wall Street. Durham, N.C.: Duke University Press. Holmes, Douglas R.

2014 Economy of Words: Communicative Imperatives in Central Banks. Chicago: University of Chicago Press.

Humphreys, Macartan, Jeffrey Sachs, and Joseph E. Stiglitz, eds.

2007 Escaping the Resource Curse. New York: Columbia University Press.

International Monetary Fund

2009 “Republic of Equatorial Guinea: Selected Issues.” Country Report. no. 09/99. https://www.imf.org/external/pubs/cat/longres.aspx?sk=22815.0.

James, C. L. R.

1938 Toussaint L'Ouverture and the San Domingo Revolution. London: Secker and Warburg.

Keynes, John Maynard

1936 The General Theory of Employment, Interest, and Money. London: Palgrave Macmillan.

1940 How to Pay for the War: A Radical Plan for the Chancellor of the Exchequer. London: Macmillan.

Kirsch, Stuart

2014 Mining Capitalism: The Relationship Between Corporations and Their Critics. Berkeley: University of California Press.

Larkin, Brian

2013 “The Politics and Poetics of Infrastructure." Annual Review of Anthropology 42:

MacKenzie, Donald 327-43. https://doi.org/10.1146/annurev-anthro-092412-155522.

2008 An Engine, Not a Camera: How Financial Models Shape Markets. Cambridge, Mass.: MIT Press. 
Maurer, Bill

2005 “Due Diligence and 'Reasonable Man,' Offshore. Cultural Anthropology 20, no. 4: 474-505. https://doi.org/10.1525/can.2005.20.4.474.

2007 "Incalculable Payments: Money, Scale, and the South African Offshore Grey Money Amnesty." African Studies Review 50, no. 2: 125-38. https://doi.org/ 10.1353/arw.2007.0109.

2011 "Mobile Money, Money Magic, Purse Limits, and Pins: Tracing Monetary Pragmatics." Journal of Cultural Economy 4, no. 3: 349-59. https://doi.org/ 10.1080/17530350.2011.586857.

2012 "Payment: Forms and Functions of Value Transfer in Contemporary Society." Cambridge Journal of Anthropology 30, no. 2: 15-35. https://doi.org/10.3167/ ca.2012.300202.

Mbembe, Achille

2001 On the Postcolony. Berkeley: University of California Press.

Mbembe, Achille, and Janet Roitman

1995 "Figures of the Subject in Times of Crisis." Public Culture 7, no. 2: 323-52. https: / /doi.org/10.1215/08992363-7-2-323.

McSherry, Brendan

2006 “The Political Economy of Oil in Equatorial Guinea." African Studies Quarterly 8, no. 3: 23-45. https://asq.africa.ufl.edu/mcsherry_spring06.

Meyer, John W., John Boli, George M. Thomas, and Francisco O. Ramirez

1997 "World Society and the Nation-State." American Journal of Sociology 103, no. 1: 144-81. https://doi.org/10.1086/231174.

Mitchell, Timothy

1998 "Fixing the Economy." Cultural Studies 12, no. 1: 82-101. https://doi.org/ 10.1080/095023898335627.

2002 Rule of Experts: Egypt, Techno-Politics, Modernity. Berkeley: University of California Press.

2011 Carbon Democracy: Political Power in the Age of Oil. New York: Verso.

2014 "Economentality: How the Future Entered Government." Critical Inquiry 40, no. 4: 479-507. https://doi.org/10.1086/676417.

Miyazaki, Hirokazu

2013 Arbitraging Japan: Dreams of Capitalism at the End of Finance. Princeton, N.J.: Princeton University Press.

Moreton-Robinson, Aileen

2015 The White Possessive: Property, Power, and Indigenous Sovereignty. Minneapolis: University of Minnesota Press.

Narotzky, Susana, and Niko Besnier

2014 "Crisis, Value, and Hope: Rethinking the Economy." Current Anthropology 55, no. S9: S4-16. https://doi.org/10.1086/676327.

Peebles, Gustav

2011 The Euro and its Rivals: Currency and the Construction of a Transnational City. Bloomington: Indiana University Press.

Pierre, Jemima

2012 The Predicament of Blackness: Postcolonial Ghana and the Politics of Race. Chicago: University of Chicago Press.

Polanyi, Karl

2001 The Great Transformation: The Political and Economic Origins of Our Time. Boston: Beacon Press. Originally published in 1944.

Polanyi, Karl, Conrad M. Arensberg, and Harry W. Pearson, eds.

1957 Trade and Market in the Early Empires: Economies in History and Theory. Glencoe, Ill.: The Free Press. 
Rae, John, and John Drury

1993 "Reification and Evidence in Rhetoric on Economic Recession: Some Methods Used in the UK Press, Final Quarter 1990.” Discourse and Society 4, no. 3: 329-

Ralph, Michael 56. https://doi.org/10.1177/0957926593004003003.

2015 Forensics of Capital. Chicago: University of Chicago Press.

República de Guinea Ecuatorial

1997 “Documento Final de la Primera Conferencia Económica Nacional.” September $8-13$.

Riles, Annelise

2011 Collateral Knowledge: Legal Reasoning in Global Financial Markets. Chicago: University of Chicago Press.

Rodney, Walter

1982 How Europe Underdeveloped Africa. Washington, DC: Howard University Press. Originally published in 1972 .

Roitman, Janet

2005 Fiscal Disobedience: An Anthropology of Economic Regulation in Central Africa. Princeton, N.J.: Princeton University Press.

Sachs, Jeffrey D., and Andrew M. Warner

1995 "Natural Resource Abundance and Economic Growth." National Bureau of Economic Research Working Paper, no. 5398. http://www.nber.org/papers/ w5398.

Sahlins, Marshall

1972 Stone Age Economics. Chicago: Aldine-Atherton.

1976 Culture and Practical Reason. Chicago: University of Chicago Press.

Speich, Daniel

2011 "The Use of Global Abstractions: National Income Accounting in the Period of Imperial Decline.” Journal of Global History 6, no. 1: 7-28. https://doi.org/ $10.1017 /$ S1740022811000027.

Stiglitz, Joseph E., Amartya Sen, and Jean-Paul Fitoussi

2010 Mismeasuring Our Lives: Why GDP Doesn't Add Up. New York: New Press.

Studenski, Paul

1958 The Income of Naitons: Theory, Measurement, and Analysis, Past and Present. New York: New York University Press.

Sundiata, Ibrahim K.

1990 Equatorial Guinea: Colonialism, State Terror, and the Search for Stability. Boulder, Colo.: Westview Press.

Tsing, Anna Lowenhaupt

2015 The Mushroom at the End of the World: On the Possibility of Life in Capitalist Ruins. Princeton, N.J.: Princeton University Press.

Vanoli, André

2005 A History of National Income Accounting. Amsterdam: IOS Press.

Welker, Marina

2014 Enacting the Corporation: An American Mining Firm in Post-Authoritarian Indonesia. Berkeley: University of California Press.

Weszkalnys, Gisa

2011 "Cursed Resources, or Articulations of Economic Theory in the Gulf of Guinea." Economy and Society 40, no. 3: 345-72. https://doi.org/10.1080/03085147. 2011.580177.

Williams, Eric

1944 Slavery and Capitalism. Chapel Hill: University of North Carolina Press.

Wolf, Eric R.

1982 Europe and the People Without History. Berkeley: University of California Press. 
Yanagisako, Sylvia Junko

2002 Producing Culture and Capital: Family Firms in Italy. Princeton, N.J.: Princeton University Press.

Young, Alden

2014 "Measuring the Sudanese Economy: A Focus on National Growth Rates and Regional Inequality, 1959-1964." Canadian Journal of Development Studies 35, no. 1: 44 -60. https://doi.org/10.1080/02255189.2014.881733.

2017 "African Bureaucrats and the Exhaustion of the Developmental State: Lessons from the Pages of the Sudanese Economist." Humanity 8, no. 1: 49-75. https:// doi.org/10.1353/hum.2017.0002. 